Revista da Faculdade de Direito da UERJ, V.2, n.22, jul./dez.2012

Pá g in a | 1

\title{
MEDIDA PROVISÓRIA: um tema urgente e relevante
}

Helena Zani Morgado ${ }^{1}$

Hugo Anciães ${ }^{2}$

\begin{abstract}
RESUMO
O presente trabalho almeja analisar não apenas a importância da Medida Provisória no ordenamento jurídico pátrio, mas também as discussões jurídicas que cercam tal instituto na atualidade. Inicialmente, serão abordados os aspectos históricos que acarretaram seu surgimento. Em seguida, o estudo debruçar-se-á sobre aspectos legais desse ato normativo e, além disso, será realizada uma minuciosa análise acerca dos pressupostos constitucionais de urgência e relevância, requisitos indispensáveis para a edição de Medidas Provisórias. Verificar-se-á, ainda, a possibilidade jurídica de utilização do instrumento pelos demais entes federativos, quais sejam, Estados e Municípios. Por fim, será realizado um exame envolvendo as vantagens e desvantagens do instituto, a fim de avaliar sua atual dimensão e compatibilidade com o princípio da separação de poderes.
\end{abstract}

PALAVRA-CHAVE: Medida Provisória. Relevância e urgência. Separação de poderes.

\section{PROVISIONAL MEASURE: an urgent and relevant subject}

\begin{abstract}
This work craves to analyze not only the importance of the Provisional Measure in the national legal system, but also the legal discussions underlying this institute nowadays. Initially, we will focus on historical aspects that led to its creation. Then, the study will look into the legal aspects of this normative act, and in addition, it will be made a detailed analysis of urgency and relevance requisites for the issuing of Provisional Measures. The possibility of the use of this legal instrument by other federal entities, namely, states and municipalities will be also verified. Finally, the advantages and disadvantages of the institute will be held in order to assess its current importance and compatibility with the principle of separation of powers.
\end{abstract}

KEY WORDS: Provisional Measure. Relevance and urgency. Separation of powers.

\section{Introdução}

Desastres naturais, calamidades, conflitos - a qualquer sociedade, se impõem situações extraordinárias que exigem esforços imediatos dos governantes. E como pode o Estado agir na forma da lei de maneira rápida e eficaz nessas circunstâncias? Foi com base nesse questionamento que ao

\footnotetext{
${ }^{1}$ Aluna de graduação do curso de Direito da Universidade do Estado do Rio de Janeiro.

${ }^{2}$ Aluno de graduação do curso de Direito da Fundação Getulio Vargas.

Artigo recebido em 31/10/2011 e aprovadoe m 06/12/2011
} 
Revista da Faculdade de Direito da UERJ, V.2, n.22, jul./dez.2012

longo do tempo se desenvolveram instrumentos análogos ao da Medida Provisória que conhecemos hoje, criados para escapar da lentidão do trâmite legislativo usual e como expressão do modelo de freios e contrapesos - enquanto função atípica ${ }^{3}$ do Poder Executivo.

O primeiro exemplo de instituto nesse sentido certamente remonta à República de Weimar. Após a derrota da Alemanha na Primeira Guerra Mundial, foi instituída no país uma Constituição que, apesar dos aspectos positivos - como a abolição de classes sociais e a equiparação de direitos entre homens e mulheres - delegava ao Presidente do Reich poderes excessivos. Além de dissolver o Parlamento e convocar as forças armadas, o chefe do Poder Executivo gozava da prerrogativa de expedir os chamados "decretos emergenciais" em situações de considerável ameaça ou perturbação à segurança e à ordem pública. Este mecanismo em princípio se prestou ao combate a perigos políticos e tentativas violentas de subversão, mas os anos expandiram cada vez mais a interpretação de seus pressupostos, levando à utilização durante dificuldades de cunho econômico, por exemplo.

Jurista de grande relevância à época, Carl Schmitt defendia idéias que agravavam ainda mais o uso indiscriminado dos decretos emergenciais. Segundo ele, estes poderiam violar todo e qualquer artigo constitucional destinado à garantia de direitos individuais, o que se justificava pela finalidade do regime ditatorial. Em suas próprias palavras: "La constitución es intangible, mientras que las leyes constitucionales pueden ser suspendidas durante el estado de excepción, y violadas por las medidas del estado de excepción."4

Dessa forma, não é difícil concluir que a destinação concedida a tais atos normativos foi determinante para o desencadeamento do processo que deu fim à República de Weimar e culminou na ascensão do nazismo ${ }^{5}$. No entanto, as consequências desastrosas do emprego desse tipo de medida não se limitaram à Alemanha. Por meio dos artigos 12 e 13 da Constituição de $1937^{6}$, o Brasil importou os decretos emergenciais sob a figura dos decretos-lei, que permaneceram no ordenamento

\footnotetext{
${ }^{3}$ José dos Santos Carvalho Filho esclarece que "não há exclusividade no exercício das funções pelos Poderes. Há, sim, preponderância. [...] Por essa razão é que os Poderes estatais, embora tenham suas funções normais (funções típicas), desempenham também funções que materialmente deveriam pertencer a Poder diverso (funções atípicas), sempre, é óbvio, que a Constituição autorize." (CARVALHO FILHO, José dos Santos. Manual de Direito Administrativo. $25^{\mathrm{a}}$ ed. Rio de Janeiro: Lumen Juris, 2010).

${ }^{4}$ Para Carl Schmitt, então, a constituição é intangível, enquanto as leis constitucionais podem ser não apenas afastadas durante o estado de exceção como também violadas pelas medidas do estado de exceção. Disponível em $\langle$ http://www.abdconst.com.br/revista3/portouniao.pdf>. Acesso em 10 out. 2011.

${ }^{5}$ ZIMMERMANN, Augusto. Curso de Direito Constitucional. $4^{a}$ ed. Rio de Janeiro: Lumen Juris, 2006. Pág. 489.

${ }^{6}$ Dispunha a Constituição de 1937:

Art. 12: O Presidente da República pode ser autorizado pelo Parlamento a expedir decretos-leis, mediante as condições e nos limites fixados pelo ato de autorização.

Art. 13: O Presidente da República, nos períodos de recesso do Parlamento ou de dissolução da Câmara dos Deputados, poderá, se o exigirem as necessidades do Estado, expedir decretos-leis sobre as matérias de competência legislativa da União, excetuadas as seguintes: a) modificações à Constituição; b) legislação eleitoral; c) orçamento; d) impostos; e) instituição de monopólios; f) moeda; g) empréstimos públicos; h) alienação e oneração de bens imóveis da União. Parágrafo único - Os decretos-leis para serem expedidos dependem de parecer do Conselho da Economia Nacional, nas matérias da sua competência consultiva.
} 
Revista da Faculdade de Direito da UERJ, V.2, n.22, jul./dez.2012

jurídico nacional até a promulgação da Constituição de 1988, tendo servido de instrumento para diversos abusos durante os governos autoritários.

As Constituições brasileiras de $1967^{7}$ e $1969^{8}$ sofreram influência dos "decreti-legge" da Constituição italiana de 1947, cujo art. 77 permite a sua adoção "in casi straordinarí di necessità e d'urgenza"9. Exemplo de tal inspiração é o art. 55 da Emenda Constitucional 01/69, que previa a expedição de decretos-lei relativos às matérias de finanças públicas, criação de cargos públicos, segurança nacional e fixação de vencimentos, desde que houvesse urgência ou relevante interesse público e que o ato não implicasse aumento de despesas. A usurpação da função legislativa pelos militares ainda era corroborada por dois fatores: a convalidação por decurso de prazo, uma vez que se o Congresso não se manifestasse o Decreto-Lei era validado; e a necessidade de apenas um pressuposto formal, qual seja, relevância ou urgência, para sua edição. Dessa forma, perpetuaram-se as bases que permitiram por tantos anos que os soberanos militares se valessem do instrumento em análise para ditar os rumos normativos do país.

Note-se, no entanto, que, apesar das semelhanças, o tratamento legal concedido ao assunto difere-se fundamentalmente na Itália e no Brasil - o que talvez explique muitos dos problemas apontados em relação ao tema em pauta. Isso porque no país europeu o governo que adota o "provimento provisório com força de lei" o faz sob sua própria responsabilidade política - dessa forma, a rejeição do ato pelo Parlamento significa a queda do Gabinete, já que, para governar, o Primeiro-Ministro necessita do apoio do Legislativo. Com efeito, até julho de 1988, a inspiração no modelo italiano encontrava respaldo em uma inclinação da Constituinte à escolha do Parlamentarismo como o sistema de governo adequado à nova realidade brasileira. Entretanto, optouse por fim pelo Presidencialismo, no qual o Chefe do Executivo não é responsabilizado politicamente pela edição de medidas emergenciais, tendo em vista que não necessita do suporte do Legislativo para governar.

\footnotetext{
${ }^{7}$ Previa a Constituição de 1967:

Art. 49: O processo legislativo compreende a elaboração de: [...] V - decretos-leis;

Art 58: O Presidente da República, em casos de urgência ou de interesse público relevante, e desde que não resulte aumento de despesa, poderá expedir decretos com força de lei sobre as seguintes matérias: I - segurança nacional; II finanças públicas. Parágrafo único: Publicado, o texto, que terá vigência imediata, o Congresso Nacional o aprovará ou rejeitará, dentro de sessenta dias, não podendo emendá-lo; se, nesse prazo, não houver deliberação o texto será tido como aprovado.

${ }^{8}$ Determinava a Emenda Constitucional 01/69:

Art. 46: O processo legislativo compreende a elaboração de: [...] V - decretos-leis;

Art 55: O Presidente da República, em casos de urgência ou de interesse público relevante, e desde que não resulte aumento de despesa, poderá expedir decretos com força de lei sobre as seguintes matérias: I - segurança nacional; II finanças públicas; III - criação de cargos públicos e fixação de vencimento. $\$ 1^{o}$ : Publicado, o texto, que terá vigência imediata, o Congresso Nacional o aprovará ou rejeitará, dentro de sessenta dias, não podendo emendá-lo; se, nesse prazo, não houver deliberação o texto será tido como aprovado. $\$ 2^{\circ}$ : A rejeição do decreto-lei não implicará a nulidade dos atos praticados durante a sua vigência.

${ }^{9}$ Isto é, a Constituição italiana de 1947 permite a edição de decretos-lei em caso de necessidade e urgência.
} 
Revista da Faculdade de Direito da UERJ, V.2, n.22, jul./dez.2012

Pág in a | 4

A Carta de Outubro, por sua vez, vinculou os atos legislativos emergenciais do Presidente da Republica tanto a requisitos semelhantes aos das Constituições anteriores, quanto a um novo regime jurídico de procedimentos e limitações, na esperança de dar fim à distorção verificada durante o período ditatorial. Como primeira expressão dessa motivação foi concedida nova denominação ao insituto: a de Medida Provisória.

\section{Aspectos legais}

A Carta Constitucional de 1988, após alteração realizada por meio da Emenda Constitucional $\mathrm{n}^{\mathrm{o}} 32 / 2001^{10}$, passou a conceder o seguinte tratamento ao tema em estudo:

Art. 62: Em caso de relevância e urgência, o Presidente da República poderá adotar medidas provisórias, com força de lei, devendo submetê-las de imediato ao Congresso Nacional.

Do artigo em questão, extraem-se, primeiramente, os pressupostos formais concomitantemente necessários - para a edição de Medidas Provisórias, quais sejam, os de relevância e urgência. Sobre eles recaem diversas discussões que serão abordadas mais adiante. A despeito das questões controvertidas, é possível perceber o caráter extraordinário concedido pelo Poder Constituinte a essa prerrogativa exclusiva do Chefe do Executivo ${ }^{11}$, o que coaduna com a já mencionada evolução que se buscava com a extinção dos decretos-lei. O Ato das Disposições Constitucionais Transitórias (ADCT), inclusive, prevê a conversão destes na nova espécie normativa $^{12}$.

Ademais, verifica-se que a Medida Provisória possui natureza dúplice: ao passo que é norma porque foi promulgada e entrou em vigor, inovando a ordem jurídica preexistente - é também projeto de lei - já que deflagra o processo legislativo, tendo prazo para ser avaliada pelo Congresso, que decidirá quanto à sua transformação definitiva em lei ${ }^{13}$. Nesse sentido, José Afonso da Silva a

\footnotetext{
${ }^{10}$ Art. 62. Em caso de relevância e urgência, o Presidente da República poderá adotar medidas provisórias, com força de lei, devendo submetê-las de imediato ao Congresso Nacional, que, estando em recesso, será convocado extraordinariamente para se reunir no prazo de cinco dias.

Parágrafo único. As medidas provisórias perderão eficácia, desde a edição, se não forem convertidas em lei no prazo de trinta dias, a partir de sua publicação, devendo o Congresso Nacional disciplinar as relações jurídicas delas decorrentes.

${ }^{11}$ Pedro Lenza enfatiza a indelegabilidade desta competência, com base na Constituição Federal, art. 84, XXVI: Compete privativamente ao Presidente da República: [...] editar medidas provisórias com força de lei, nos termos do art. 62. (LENZA, Pedro. Direito Constitucional Esquematizado. 15 a ed. São Paulo: Saraiva, 2011).

${ }^{12}$ ADCT, art. $25, \$ 2^{\circ}$ : Os decretos-lei editados entre 3 de setembro de 1988 e a promulgação da Constituição serão convertidos, nesta data, em medidas provisórias, aplicando-se-lhes as regras estabelecidas no art. 62, parágrafo único.

${ }^{13}$ Tal processo se encontra amplamente detalhado na Constituição, art. 62, $\S \S 3^{\circ}$ a 12.
} 
Revista da Faculdade de Direito da UERJ, V.2, n.22, jul./dez.2012

classifica como medida de lei sujeita a uma condição resolutiva ${ }^{14}$, vinculada à deliberação da Câmara dos Deputados e do Senado Federal.

Note-se que, enquanto lei em sentido material, a Medida Provisória tem o condão de suspender a eficácia de normas que com ela sejam incompatíveis, sendo esse efeito cessado em caso de sua rejeição no Congresso. Nessa hipótese, o Legislativo deve disciplinar as relações jurídicas dela decorrentes por meio de um decreto legislativo ${ }^{15}$. Por outro lado, ocorrendo a conversão em lei, esta revogará os dispositivos legais em contrário, até então suspensos, com fundamento no critério cronológico de solução de antinomias ${ }^{16}$.

A Emenda Constitucional $n^{\circ} 32 / 01$ trouxe ao tema nova regra, que estabelece que, após sua adoção pelo Presidente da República, a Medida Provisória irá vigorar pelo prazo de sessenta dias, prorrogável uma única vez e por igual período, contado da publicação no Diário Oficial ${ }^{17}$. A submissão ao Congresso será imediata, ficando a cargo de uma Comissão composta por deputados e senadores avaliar sua adequação financeira e orçamentária, bem como seus aspectos constitucionais ${ }^{18}$ e de mérito. Essa apreciação resultará em um parecer, encaminhado à Câmara dos Deputados e ao Senado Federal, locais aonde se processará votação em separado pelo plenário de cada Casa.

Do crivo das comissões serão possíveis três resultados práticos: a aprovação da medida sem qualquer alteração, a aprovação com alteração e, ainda, a rejeição expressa do ato presidencial. Transcorridos sessenta dias da prorrogação para a apreciação da medida, sem que haja decisão, ocorre rejeição tácita, na qual se sujeita o ato à perda de eficácia com efeitos retroativos - ex tunc que ratificam seu caráter efêmero. ${ }^{19}$

Ainda em relação aos aspectos procedimentais do tema, é fundamental destacar o disposto no art. $62, \S 6^{\circ 20}$, que prevê o trancamento de pauta da Casa Legislativa que não proceder à apreciação da Medida Provisória em quarenta e cinco dias, contados de sua publicação. É o chamado regime de

\footnotetext{
${ }^{14}$ SILVA, José Afonso da. Curso de Direito Constitucional Positivo. 27 a ed. São Paulo: Malheiros, 2006. Pág. 531.

${ }^{15}$ Art. 62, $\$ 3^{\circ}$ : As medidas provisórias, ressalvado o disposto nos $\$ \$ 11$ e 12 perderão eficácia, desde a edição, se não forem convertidas em lei no prazo de sessenta dias, prorrogável, nos termos do $\$ 7^{\circ}$, uma vez por igual período, devendo o Congresso Nacional disciplinar, por decreto legislativo, as relações jurídicas delas decorrentes.

${ }^{16}$ Código Civil, art. $2^{o}, \xi 1^{o}$ : A lei posterior revoga a anterior quando expressamente o declare, quando seja com ela incompatível ou quando regule inteiramente a matéria de que tratava a lei anterior.

${ }^{17}$ Ressalte-se que o referido prazo poderá ser suspenso em caso de recesso parlamentar, na forma do art. $62, \S 4^{\circ}$.

${ }^{18}$ A deliberação de cada uma das Casas do Congresso Nacional também depende de juízo prévio sobre os requisitos de urgência e relevância.

${ }^{19}$ Conforme já mencionado, neste aspecto as Medidas Provisórias diferem-se substancialmente dos Decretos-Lei. Até o advento da Constituição de 1988, o decurso de prazo sem deliberação do Congresso Nacional acarretava a aprovação tácita.

${ }^{20}$ Art. 62, $\$ 6^{\circ}$ : Se a medida provisória não for apreciada em até quarenta e cinco dias contados de sua publicação, entrará em regime de urgência, subseqüentemente, em cada uma das Casas do Congresso Nacional, ficando sobrestadas, até que se ultime a votação, todas as demais deliberações legislativas da Casa em que estiver tramitando.
} 
urgência, que tem o condão de sobrestar todas as matérias da Casa na qual se encontra ${ }^{21}$. José Afonso da Silva argumenta que há uma incoerência entre esse dispositivo e aquele que prevê que, se as Medidas Provisórias não forem analisadas em sessenta dias, prorrogáveis por uma única vez, perderão sua eficácia. Isso porque o par. $6^{\circ}$ estabelece que todas deverão ser objeto de votação, processo por meio do qual elas serão tão-somente aprovadas ou rejeitadas, sem margem legal alguma para a perda de eficácia por não apreciação ${ }^{22}$.

De fato, o regime de urgência, combinado com o elevado número de Medidas Provisórias editadas pelo Presidente da República, implicou uma considerável paralisia do Poder Legislativo brasileiro. Em face dessa realidade, Michel Temer, à época Presidente da Câmara dos Deputados, desenvolveu uma tese jurídica defendendo a interpretação sistemática, e não literal, do dispositivo com base no argumento de que o trancamento deveria se restringir apenas às apreciações cujas matérias pudessem ser tratadas por Medidas Provisórias ${ }^{23}$. Dessa forma, resoluções, decretos legislativos, projetos de Lei Complementar e propostas de Emenda Constitucional poderiam continuar em votação em sessões extraordinárias ${ }^{24}$. Essa interpretação foi objeto de intenso debate na doutrina e chegou a ser analisado pelo Supremo Tribunal Federal, em sede de mandado de $\operatorname{segurança~}^{25}$ impetrado pelos então líderes do PPS, do DEM e do PSDB, que contestavam a interpretação concedida pelo atual Vice-Presidente da República. A matéria ainda está pendente de julgamento definitivo, mas o Ministro Relator Celso de Mello $^{26}$ indeferiu a liminar, prezando pela aplicação sistemática do dispositivo constitucional.

Analisado o trâmite das Medidas Provisórias, urge abordar as limitações materiais às quais estas se submetem, comumente categorizadas pela doutrina ${ }^{27}$ como explícitas e implícitas. As primeiras se referem às proibições expressas em comando literal, instituídas pela Emenda Constitucional $n^{\circ} 32$ :

\footnotetext{
${ }^{21}$ É válido enfatizar que o prazo de quarenta e cinco dias é contabilizado de forma conjunta, isto é, se a Câmara dos Deputados votar a Medida Provisória no $44^{\circ}$ dia após sua publicação, a mesma já chegará ao Senado trancando sua pauta de votação - a chegada ao Senado não enseja um novo prazo de quarenta e cinco dias. Dessa forma, é fácil concluir que sempre que houver trancamento de pauta na Câmara, ocorrerá trancamento de pauta quando do envio à outra Casa.

${ }^{22}$ SILVA, José Afonso da. Curso de Direito Positivo. 23 ed. São Paulo: Malheiros, 2003. Pág. 531.

${ }^{23}$ Disponível em <http://www.stf.jus.br/portal/cms/verNoticiaDetalhe.asp?idConteudo=105404>. Acesso em 15 out. 2011.

24 Disponível em <http://oab-ba.jusbrasil.com.br/noticias/951678/regra-para-trancamento-da-pauta-por-mp-econtestada>. Acesso em 15 out. 2011.

${ }^{25}$ Mandado de Segurança ${ }^{\circ}$ 27.931, DF, Rel. Min. Celso de Mello.

${ }^{26}$ Para o Ministro Relator, a interpretação de Temer reflete, com fidelidade, uma solução jurídica plenamente compatível com o modelo teórico da separação de poderes, haja vista que revela fórmula hermenêutica capaz de assegurar uma adequada relação de equilíbrio entre as instâncias governamentais do Executivo e do Legislativo e, em última instância, a própria integridade da cláusula pertinente à divisão de poder. Deu, ainda, interpretação conforme a Constituição, sem redução do texto, do art. $62, \S 6^{\circ}$, para restringir-lhe a exegese, fixando entendimento de que tal regime constitucional que impõe o sobrestamento das deliberações legislativas das Casas do Congresso Nacional refere-se, apenas, àquelas matérias que se mostrem passíveis de regramento por medida provisória.

${ }^{27}$ MORAES, Guilherme Peña de. Curso de Direito Constitucional. $2^{\mathrm{a}}$ ed. Rio de Janeiro: Impetus, 2008.
} 
Revista da Faculdade de Direito da UERJ, V.2, n.22, jul./dez.2012

Pá g in a | 7

Art. 62: $[\ldots]$

$\S 1^{\circ}$ É vedada a edição de medidas provisórias sobre matéria:

I - relativa a:

a) nacionalidade, cidadania, direitos políticos, partidos políticos e direito eleitoral;

b) direito penal, processual penal e processual civil;

c) organização do Poder Judiciário e do Ministério Público, a carreira e a garantia de seus membros;

d) planos plurianuais, diretrizes orçamentárias, orçamento e créditos adicionais e suplementares, ressalvado o previsto no art. $167, \S 3^{\circ}$;

II - que vise a detenção ou seqüestro de bens, de poupança popular ou qualquer outro ativo financeiro;

III - reservada a lei complementar;

IV - já disciplinada em projeto de lei aprovado pelo Congresso Nacional e pendente de sanção ou veto do Presidente da República.

Dentre os limites implícitos, originários de uma interpretação sistemática da Constituição, encontram-se os direitos fundamentais, os quais, em que pese o silêncio legal, sujeitam-se à reserva de lei ${ }^{28}$. Também são matérias sujeitas à mesma restrição as de atribuição exclusiva ou privativa do Congresso, da Câmara dos Deputados, do Senado Federal, do Poder Judiciário, do Ministério Público e dos Tribunais de Contas; as que na mesma sessão legislativa tenham sido rejeitadas pelo Congresso; e as próprias de codificação.

Outro limite material está previsto no art. 246 na Carta de Outubro, que veda a edição de Medidas Provisórias que regulem normas constitucionais modificadas por emenda constitucional entre janeiro de 1995 e a Emenda Constitucional no 32 de 2001.

Ademais, o art. 73 do ADCT, incluído pela Emenda Constitucional de Revisão no 1 de 1994, proíbe o uso do instituto em estudo em regulação constitucional ainda mais específica, a do Fundo Social de Emergência ${ }^{29}$.

Outra questão importante diz respeito à possibilidade de edição de Medida Provisória sobre matéria tributária. Vejamos o que diz o parágrafo $2^{\circ}$ do já referido artigo 62 :

Art. $62, \S 2^{\circ}$ : Medida provisória que implique instituição ou majoração de impostos, exceto os previstos nos arts. 153, I, II, IV, V, e 154, II, só produzirá efeitos no exercício financeiro seguinte se houver sido convertida em lei até o último dia daquele em que foi editada.

A análise do dispositivo em tela nos permite concluir que, em regra, a Medida Provisória estará sujeita ao principio da anterioridade tributária e só produzirá efeitos no exercício seguinte se

\footnotetext{
${ }^{28}$ Os direitos fundamentais são garantidos pela Constituição a todos os seres humanos para que estes possam se defender contra eventuais abusos do Estado e de outros particulares. Essas garantias, por razões lógicas, não são absolutas, pois a convivência com outros direitos acarreta conflitos cuja solução só é possível com a relativização, por meio do exame de ponderação. Ademais, não é qualquer norma que pode restringir os direitos fundamentais: são apenas leis. Aceitar a possibilidade de restrição por Medida Provisória, por exemplo, seria subverter o próprio Estado Democrático de Direito, pois significaria deixar as minorias ao livre-arbítrio da vontade do soberano. A restrição a direitos fundamentais, portanto, está sujeita ao princípio da reserva legal.

${ }^{29}$ ADCT, Art. 73. Na regulação do Fundo Social de Emergência não poderá ser utilizado o instrumento previsto no inciso $V$ do art. 59 da Constituição.
} 
Revista da Faculdade de Direito da UERJ, V.2, n.22, jul./dez.2012

houver sido convertida em lei até o último dia do ano em que foi editada. No entanto, são feitas exceções a esse comando geral, na hipótese de instituição ou aumento de impostos sobre importação de produtos estrangeiros (II), exportação de produtos nacionais ou nacionalizados para o exterior (IE), de operações de crédito, câmbio e seguro, ou relativas a títulos e valores mobiliários (IOF) e de impostos extraordinários de guerra (IEG). Nesses casos, a Medida Provisória produzirá efeitos desde a sua edição.

Contudo, como bem alertam Vicente Paulo e Marcelo Alexandrino ${ }^{30}$, no caso do imposto sobre produtos industrializados (IPI), previsto no artigo 153, IV da Constituição, deverá ser respeitado um período de 90 dias para que a medida passe a produzir efeitos. Isso por conta da alínea “c", inciso III, do artigo $150^{31}$, que estabelece a regra da "noventena" na medida em que determina um prazo mínimo de noventa dias para a produção de efeitos de leis que instituam ou aumentem tributos, acentuando ainda mais a proteção do cidadão-contribuinte. É o que comprova a recente decisão do $\mathrm{STF}^{32}$, proferida dia 20 de outubro de 2011, que suspendeu o aumento de IPI para carros importados, elevado pelo governo em trinta pontos percentuais, até dezembro, isto é, noventa dias após a publicação do Decreto $\mathrm{n}^{\mathrm{0}} 7.567 / 11^{33}$. Note-se que os demais impostos anteriormente citados se enquadram na exceção prevista no parágrafo $1^{\circ}$ do art. $150^{34}$, motivo pelo qual não se submetem à anterioridade nonagesimal.

Já no tocante a outras espécies tributárias sujeitas ao princípio da anterioridade, como as taxas e as contribuições de melhoria, a Medida Provisória produzirá efeitos apenas no ano seguinte ao de sua publicação, ainda que não tenha sido convertida em lei no mesmo ano em que foi editada, exigindo-se, contudo, que aguarde o transcurso do prazo de noventa dias após sua publicação.

Finalmente, há uma vedação material às Medidas Provisórias estaduais ${ }^{35}$, prevista no parágrafo $2^{\circ}$ do artigo 25 da $\mathrm{CF}$, qual seja para a regulamentação da exploração do gás canalizado.

Outro tema que merece destaque é o que concerne à natureza jurídica da Medida Provisória, objeto de divergências doutrinárias no passado. O Supremo Tribunal Federal, em julgamento

\footnotetext{
${ }^{30}$ PAULO, Vicente; ALEXANDRINO, Marcelo. Direito Constitucional Descomplicado. $7^{\mathrm{a}}$ ed. São Paulo: Método, 2011. Pág. 546.

${ }^{31}$ Art. 150. Sem prejuízo de outras garantias asseguradas ao contribuinte, é vedado à União, aos Estados, ao Distrito Federal e aos Municípios: [...] III - cobrar tributos: [...] c) antes de decorridos noventa dias da data em que haja sido publicada a lei que os instituiu ou aumentou, observado o disposto na alínea $b$.

${ }_{33}^{32}$ Decisão proferida na ADIn no 4661 proposta pelo Democratas (DEM). Rel. Min. Marco Aurélio.

33 Disponível em <http://economia.terra.com.br/noticias/noticia.aspx?idNoticia=201110201823_TRR_ 80369639>. Acesso em 22 out. 2011.

${ }^{34}$ Art. 150. Sem prejuízo de outras garantias asseguradas ao contribuinte, é vedado à União, aos Estados, ao Distrito Federal e aos Municípios: [...] $\$ 1^{\circ}$ : A vedação do inciso III, b, não se aplica aos tributos previstos nos arts. 148, I, 153, I, II, IV e V; e 154, II; e a vedação do inciso III, c, não se aplica aos tributos previstos nos arts. 148, I, 153, I, II, III e V; e 154, II, nem à fixação da base de cálculo dos impostos previstos nos arts. 155, III, e 156, I.

${ }^{35}$ Sobre este tema, ver tópico 4: "Ato privativo do Presidente da República? A possibilidade de edição de Medidas Provisórias por Estados e Municípios."
} 
Revista da Faculdade de Direito da UERJ, V.2, n.22, jul./dez.2012

Pá g in a $\mid 9$

proferido na Ação Direta de Inconstitucionalidade n ${ }^{\circ} 293$, pacificou entendimento assinalando que a Medida Provisória seria um ato normativo primário:

As medidas provisórias configuram, no Direito Constitucional brasileiro, uma categoria especial de atos normativos primários emanados do Poder Executivo, que se revestem de força, eficácia e valor de lei ${ }^{36}$.

Apesar de possuir um caráter de transitoriedade, enquanto espécie normativa definitiva e acabada, a Medida Provisória está sujeita ao controle de constitucionalidade tanto em relação ao seu conteúdo material, em regra, como também no tocante aos pressupostos de relevância e urgência, em caráter excepcional, como será explicitado em tópico oportuno ${ }^{37}$. Neste sentido, não estaria José Afonso da Silva revestido de razão em sua crítica no tocante à natureza normativa das Medidas Provisórias $^{38}$, uma vez que, se essas não fossem espécies normativas, não poderiam ser objeto de Ação Direita de Inconstitucionalidade.

\section{Urgência e Relevância: controle e hipóteses}

Como visto anteriormente, o artigo 62 da Constituição estabelece como requisito para a edição de Medidas Provisórias a presença dos pressupostos de urgência e relevância. O Constituinte, ao não determinar quais seriam as situações relevantes e urgentes, concedeu a esses requisitos caráter de "cláusulas abertas", passíveis de interpretações variadas ao longo do tempo e do espaço. Não é tarefa fácil, pois, identificar os contornos constitucionais que englobam esses pressupostos. Há interesses antagônicos em jogo: de um lado, a separação de poderes e a democracia; de outro, o interesse público e a morosidade do processo legislativo.

Clève $^{39}$, com propriedade, afirma que é relevante o que é proeminente, importante, fundamental, essencial ou indispensável em relação a determinada sociedade. O conceito de relevância está atrelado, então, ao interesse público. O vocábulo constitucional se refere aos casos mais graves e importantes, que demandam atuação imediata do Estado ${ }^{40}$. Urgente, por sua vez, é tudo aquilo que não pode aguardar o decurso do tempo, que deve ser realizado prontamente. $\mathrm{O}$ contexto fático que requer a edição da medida deve ser iminente e inadiável.

\footnotetext{
${ }^{36}$ Decisão proferida na ADIn no 293, Rel. Min. Celso de Mello. J. 06 jun. 1990, DJU 16 abr. 1993.

${ }^{37}$ Sobre este tema, ver próximo tópico: Urgência e Relevância: controle e hipóteses.

${ }^{38}$ Para o referido autor, a Medida Provisória seria um "ato legislativo submetido a condição resolutiva", posto que sujeito a perder sua qualificação legal no período de sessenta dias. (FERNANDES, Bernardo Gonçalves. Curso de Direito Constitucional. $2^{\text {a }}$ Ed. Rio de Janeiro: Lumen Juris, 2010. Pp. 662 e 663).

${ }^{39}$ CLÈVE, Clèmerson Merlin. Medidas Provisórias. $2^{\text {a }}$ ed. São Paulo: Max Limonad, 1999.

${ }^{40}$ BALERA, Felipe Penteado. Medida Provisória: o controle dos requisitos constitucionais de relevância e urgência pelo Congresso Nacional e pelo STF. Disponível em <http://www.esdc.com.br/RBDC/RBDC-14/RBDC-14-025Artigo_Felipe_Penteado_Balera_(Medida_Provisoria).pdf>. Acesso em 21 out. 2011.
} 
Revista da Faculdade de Direito da UERJ, V.2, n.22, jul./dez.2012

Página | 10

Definidos os pressupostos constitucionais para a adoção de Medida Provisória pelo Chefe do Executivo, cabe, agora, analisarmos quem é responsável pela aferição desses requisitos. O parágrafo $5^{\circ}$ do artigo 62, já mencionado, determina que cabe ao Congresso Nacional, além de fiscalizar os aspectos políticos, realizar o controle jurídico do instituto, que engloba a verificação da presença da relevância e da urgência. Lamentavelmente, porém, o Poder Legislativo tem relegado a segundo plano essa prerrogativa, o que resulta na conversão em lei de várias Medidas Provisórias inconstitucionais.

Diante da irrisória eficácia do crivo jurídico da Câmara dos Deputados e do Senado Federal, praticamente reduzido a questões políticas, interessante questão se coloca a respeito da possibilidade de controle pelo Poder Judiciário. Em relação à fiscalização "material”, é pacífico que, como ato normativo, as Medidas Provisórias sujeitam-se ao controle de constitucionalidade pelo Supremo Tribunal Federal ${ }^{41}$. Já no tocante aos pressupostos de relevância e urgência, faz-se necessária uma análise mais detalhada no presente estudo.

Durante o período militar, a Corte Suprema, por razões óbvias, não se debruçava sobre os requisitos dos decretos-lei, argumentando que estes diziam respeito a uma decisão política do Presidente. Com a promulgação da Constituição de 1988, os ministros nomeados durante a ditadura permaneceram como membros do Tribunal. Não é difícil concluir, pois, que a jurisprudência anterior se manteve em relação às Medidas Provisórias, caracterizando o que o professor Luis Roberto Barroso denominou de "interpretação retrospectiva":

uma das patologias crônicas da hermenêutica constitucional é a interpretação retrospectiva, pela qual se procura interpretar o texto novo de maneira a que ele não inove nada, mas, ao revés, fique tão parecido quanto o possível com o antigo ${ }^{42}$.

A Constituição, como sistema aberto, deve ser interpretada à luz do contexto sócio-político vigente, devendo desatar-se das amarras hermenêuticas passadas. Conforme mencionado, porém, os ministros permaneceram atados ao passado, em uma posição totalmente acrítica - apesar do contexto democrático, continuaram esquivando-se do controle dos pressupostos de urgência e relevância. Havia, então, problemas nas três esferas do governo: o Executivo editava medidas provisórias em excesso, o Legislativo assistia apático e o Judiciário se abstinha.

Diante da continuidade de tal cenário de anti-judicialização da política por mais de uma década, em 11 de setembro de 2001 foi aprovada a Emenda Constitucional n 32, responsável por conferir a atual redação do artigo 62. Sendo clara a ratio legis do constituinte derivado em reduzir o

\footnotetext{
${ }^{41}$ Art. 102. Compete ao Supremo Tribunal Federal, precipuamente, a guarda da Constituição, cabendo-lhe: I - processar e julgar, originariamente: a) a ação direta de inconstitucionalidade de lei ou ato normativo federal ou estadual e a ação declaratória de constitucionalidade de lei ou ato normativo federal.

${ }^{42}$ Disponível em <http://www.sefaz.pe.gov.br/flexpub/versaol/filesdirectory/sessions579.pdf>. Acesso em 27 out. 2011.
} 
extenso número de Medidas Provisórias, além de vedar a possibilidade de reedição do ato normativo na mesma sessão legislativa ${ }^{43}$ e de instituir limites materiais, a Emenda $n^{\circ} 32$ foi fundamental à mudança de orientação jurisprudencial no tocante ao controle dos pressupostos de urgência e relevância.

O posicionamento atual do Pretório Excelso é inadmiti-lo por invasão na esfera discricionária do Executivo, salvo quando flagrante o desvio de finalidade ou abuso de poder de legislar. Entende, portanto, que a inconstitucionalidade formal deve ser analisada apenas excepcionalmente. Neste sentido, adotou o seguinte entendimento no julgamento da ADIn 2213, in verbis:

A edição de medidas provisórias, pelo Presidente da República, para legitimar-se juridicamente, depende, dentre outros requisitos, da estrita observância dos pressupostos constitucionais da urgência e da relevância (CF, art. 62, "caput"). - Os pressupostos da urgência e da relevância, embora conceitos jurídicos relativamente indeterminados e fluidos, mesmo expondo-se, inicialmente, à avaliação discricionária do Presidente da República, estão sujeitos, ainda que excepcionalmente, ao controle do Poder Judiciário, porque compõem a própria estrutura constitucional que disciplina as medidas provisórias, qualificando-se como requisitos legitimadores e juridicamente condicionantes do exercício, pelo Chefe do Poder Executivo, da competência normativa primária que lhe foi outorgada, extraordinariamente, pela Constituição da República. Doutrina. Precedentes. - A possibilidade de controle jurisdicional, mesmo sendo excepcional, apóia-se na necessidade de impedir que o Presidente da República, ao editar medidas provisórias, incida em excesso de poder ou em situação de manifesto abuso institucional, pois o sistema de limitação de poderes não permite que práticas governamentais abusivas venham a prevalecer sobre os postulados constitucionais que informam a concepção democrática de Poder e de Estado, especialmente naquelas hipóteses em que se registrar o exercício anômalo e arbitrário das funções estatais. UTILIZAÇÃO ABUSIVA DE MEDIDAS PROVISÓRIAS - INADMISSIBILIDADE - PRINCÍPIO DA SEPARAÇÃO DOS PODERES - COMPETÊNCIA EXTRAORDINÁRIA DO PRESIDENTE DA REPÚBLICA. - A crescente apropriação institucional do poder de legislar, por parte dos sucessivos Presidentes da República, tem despertado graves preocupações de ordem jurídica, em razão do fato de a utilização excessiva das medidas provisórias causar profundas distorções que se projetam no plano das relações políticas entre os Poderes Executivo e Legislativo. Nada pode justificar a utilização abusiva de medidas provisórias, sob pena de o Executivo - quando ausentes razões constitucionais de urgência,necessidade e relevância material -, investir-se, ilegitimamente, na mais relevante função institucional que pertence ao Congresso Nacional, vindo a converter-se, no âmbito da comunidade estatal, em instância hegemônica de poder, afetando, desse modo, com grave prejuízo para o regime das liberdades públicas e sérios reflexos sobre o sistema de "checks and balances", a relação de equilíbrio que necessariamente deve existir entre os Poderes da República. Cabe, ao Poder Judiciário, no desempenho das funções que lhe são inerentes, impedir que o exercício compulsivo da competência extraordinária de editar medida provisória culmine por introduzir, no processo institucional brasileiro, em matéria legislativa, verdadeiro cesarismo governamental, provocando, assim, graves distorções

\footnotetext{
${ }^{43}$ Art. 62, \$10: É vedada a reedição, na mesma sessão legislativa, de medida provisória que tenha sido rejeitada ou que tenha perdido sua eficácia por decurso de prazo.
} 
Revista da Faculdade de Direito da UERJ, V.2, n.22, jul./dez.2012

Página | 12

no modelo político e gerando sérias disfunções comprometedoras da integridade do princípio constitucional da separação de poderes. ${ }^{44}$

Em princípio, então, determina o Supremo Tribunal Federal que os requisitos de urgência e relevância devem ser analisados pelo próprio Chefe do Executivo, no momento da edição da Medida Provisória, e pelo Congresso Nacional que, se não verificá-los, poderá deixar de convertê-la em lei. Excepcionalmente, porém, quando se aferir desvio de finalidade ou abuso de poder de legislar por flagrante inexistência destes pressupostos constitucionais, poderá o Judiciário interferir na esfera discricionária do Executivo.

Em que pese o indubitável avanço em relação à omissão de outrora, data vênia ousamos discordar da posição adotada pela Corte Constitucional. "Urgência" e "relevância" não atribuem, por si só, discricionariedade política ao Presidente, mas sim se apresentam como conceitos jurídicos indeterminados. Note-se que, embora em ambos os casos exista uma imprecisão semântica, o modo de controle exercido em cada hipótese será distinto, uma vez que é segura na jurisprudência a concepção de que atos discricionários podem ser controlados apenas em caso de abuso extremo ou erro grave.

Não se pode falar em discricionariedade apenas pela vinculação da edição de Medidas Provisórias à exclusiva iniciativa do Chefe do Executivo. Isso porque essa prerrogativa está limitada à existência de pressupostos de urgência e relevância, considerados merecedores de inserção na Carta Magna pelo Poder Constituinte originário. Não basta a simples manifestação de vontade para editar o ato normativo em tela: é preciso que se verifiquem requisitos de admissibilidade no caso concreto. Dessa forma, com base nos princípios da separação de poderes e da legalidade, é correto arguir pela indeterminação destes conceitos jurídicos. Para corroborar essa tese, há ainda o fato do uso da Medida Provisória acarretar uma zona de conflito entre o Executivo e o Legislativo, fazendo-se importante que o Judiciário atue como um árbitro imparcial.

Neste sentido, assiste razão aos Ministros Sepúlveda Pertence e Celso de Mello, que firmaram entendimento diverso do relator na ADIn acima analisada. Para o último,

o reconhecimento da imunidade jurisdicional, que pré-excluísse, de apreciação judicial o exame de tais pressupostos - caso fosse admitido - implicaria consagrar, de modo inaceitável, em favor do Presidente da República, uma ilimitada expansão de seu poder para editar medidas provisórias sem qualquer possibilidade de controle, o que se revelaria incompatível com o nosso sistema constitucional. ${ }^{45}$

\footnotetext{
44 Julgamento proferido pelo Pleno do STF na ADIn 2213/DF em sede de medida cautelar. Rel. Min. Celso de Mello. 2002.

${ }^{45}$ Voto do Ministro Celso de Mello no julgamento da ADIn 162-1/DF.
} 
Revista da Faculdade de Direito da UERJ, V.2, n.22, jul./dez.2012

Página | 13

Neste diapasão, em sede doutrinária, Celso Antônio Bandeira de Mello brilhantemente aduz que:

o Judiciário não sai de seu campo próprio nem invade discrição administrativa quando verifica se pressupostos normativamente estabelecidos para delimitar uma dada competência existem ou não existem. Uma vez que a Constituição só admite medidas provisórias em face de situação relevante e urgente, segue-se que ambos são, cumulativamente, requisitos indispensáveis para irrupção da aludida competência. É dizer: sem eles inexistirá poder para editá-las. Se a Carta Magna tolerasse edição de medidas de emergência fora destas hipóteses, não haveria condicionado sua expedição à pré-ocorrência destes supostos normativos. Segue-se que têm de ser judicialmente controlados, sob pena de ignorar-se o balizamento constitucional da competência para editar medidas provisórias. Com efeito, se 'relevância e urgência' fossem noções só aferíveis concretamente pelo Presidente da República, em juízo discricionário incontrastável, o delineamento e a extensão da competência para produzir tais medidas não decorreriam da Constituição, mas da vontade do Presidente, pois teriam o âmbito que o Chefe do Executivo lhes quisesse dar. Assim, ao invés de estar limitado por um círculo de poderes estabelecidos pelo Direito, ele é quem decidiria sua própria esfera competencial na matéria, idéia antinômica a tudo que resulta do Estado de Direito. ${ }^{46}$

Ademais, vige ainda o princípio da inafastabilidade do controle jurisdicional, previsto no artigo $5^{\circ}, \mathrm{XXXV}$ da Carta Magna, segundo o qual "a lei não excluirá da apreciação do Poder Judiciário lesão ou ameaça a direito". Como guardião da Constituição, a escusa do exame acerca da presença dos pressupostos de urgência e relevância pelo Judiciário implica violação das atribuições constitucionais do próprio Supremo Tribunal Federal.

\subsection{Medidas Provisórias relacionadas a matérias tributárias e a violação do requisito de urgência}

Como visto anteriormente, salvo as exceções previstas no parágrafo $2^{\circ}$ do artigo 62 da Constituição, as Medidas Provisórias que impliquem instituição ou majoração de tributos só produzirão efeitos no ano seguinte ao de sua publicação, com fundamento no princípio da anterioridade.

É inquestionável, enfatize-se, que tal princípio possui extrema importância para a segurança jurídica e proteção do cidadão-contribuinte. Portanto, qualquer lei que crie ou aumente tributos deve respeitá-lo.

Ocorre que, como já visto, as Medidas Provisórias só podem ser editadas na presença dos pressupostos constitucionais de relevância e urgência. Ora, não é difícil constatar que, ainda que relevante, uma questão que permite a espera por um ano para começar a produzir efeitos simplesmente não pode tratar-se de algo urgente.

\footnotetext{
${ }^{46}$ MELLO, Celso Antônio Bandeira de. Curso de Direito Administrativo. 20a ed. São Paulo: Malheiros, 2006. Pág. 120.
} 
Revista da Faculdade de Direito da UERJ, V.2, n.22, jul./dez.2012

Página | 14

A Carta de Outubro estabeleceu um procedimento legislativo sumário para os casos em que o Presidente solicitar urgência em projetos de sua iniciativa. O artigo 64 determina que cada Casa Legislativa possui quarenta e cinco dias para apreciar o projeto, totalizando noventa dias. Em caso de emenda do Senado, a Câmara dispõe de mais dez dias para proceder sua análise. Dessa forma, o instrumento das Medidas Provisórias não seria adequado ao tratamento de matérias que pudessem aguardar até cem dias sem sofrer dano ou prejuízo.

Neste sentido, constata-se que se a própria Constituição Federal determinou que o assunto que pode aguardar cem dias para produzir efeitos não preenche os pressupostos inerentes ao instituto em estudo, com muito mais razão não o faria aquele que pudesse esperar por um ano. Dessarte, o artigo 150, ao vedar a cobrança de tributos no mesmo ano do exercício financeiro da lei que o instituiu, constitui limite material à edição de medidas provisórias. Assim, só seria possível a edição desses atos normativos acerca dos impostos mencionados no parágrafo primeiro do mesmo artigo 150, quais sejam, aqueles não sujeitos ao princípio da anterioridade.

Ressalte-se que muitos tributaristas ${ }^{47}$ concordam com o argumento acima defendido, porém partem de outra premissa: a equiparação com o direito penal. Aduzem que os dois ramos do direito possuem os mesmos valores garantistas e que, com base no princípio da legalidade estrita, não podem ser regulados por Medida Provisória. Isso porque, se no âmbito penal a Carta Magna afirma que não há crime sem lei anterior que o defina, nem pena sem prévia cominação legal ${ }^{48}$, há na esfera tributária necessidade de observância ao preceito constitucional que disciplina sobre a impossibilidade de existência ou aumento de tributo sem lei que o estabeleça ${ }^{49}$. No nosso entender, resta evidente que tal leitura está equivocada. Paralelismos entre patrimônio e liberdade só podem se sustentar a partir de uma concepção classista e estritamente burguesa da Constituição.

Em contraposição ao que foi exposto, porém, até o momento é pacífica na jurisprudência a possibilidade de adoção de Medidas Provisórias em matéria tributária.

\section{Ato privativo do Presidente da República? A possibilidade de edição de Medidas Provisórias por Estados e Municípios}

\footnotetext{
${ }^{47}$ No mesmo sentido, ver: ATALIBA, Geraldo. Hipótese de incidência tributária. São Paulo: Malheiros, 2004; DERZI; MACHADO, Misabel de Abreu. Direito tributário, direito penal e tipo. São Paulo: RT, 1988; MENDES, Danielle Patrícia Guimarães. A medida provisória sobre matéria tributária em face da Emenda Constitucional $n^{\circ} 32$. Jus Navigandi, Teresina, ano 7, n. 58, 1 ago. 2002. Disponível em: $\lfloor$ http://jus.com.br/revista/texto/3084>. Acesso em: 3 dez. 2011.

${ }^{48} \mathrm{CF}$, art. $5^{\circ}$, XXXIX : Não há crime sem lei anterior que o defina, nem pena sem prévia cominação legal

${ }^{49} \mathrm{CF}$, art. 150, I: Sem prejuízo de outras garantias asseguradas ao contribuinte, é vedado à União, aos Estados, ao Distrito Federal e aos Municípios: I - exigir ou aumentar tributo sem lei que o estabeleça;
} 
Revista da Faculdade de Direito da UERJ, V.2, n.22, jul./dez.2012

Página | 15

Questão interessante se coloca acerca da possibilidade de edição de Medidas Provisórias pelos Estados-membros e Municípios. De um lado, reside o argumento contrário ao detrimento dos princípios da separação de poderes e da legalidade em favor do princípio da simetria. Para essa corrente, as próprias regras do processo legislativo situam o instituto como excepcional e exclusivo da União. Ademais, foi visto que a edição de medida provisória depende de um contexto de periculum in mora legislativo. É notório que o processo legislativo federal é mais lento que o estadual e que o municipal, pois no primeiro há o bicameralismo. Existe um receio de que, se os Prefeitos, por exemplo, usarem esse ato normativo, haverá na prática o fechamento da Câmara dos Vereadores. Finalmente, o argumento mais cético contra a edição de Medidas Provisórias pelos outros entes federativos se baseia em uma "provável" extensão da banalização do uso desse instituto, haja vista que, se na esfera federal - onde o controle da sociedade, do Poder Legislativo e dos meios de comunicação é maior - este processo se verifica, que dirá nos Estados e Municípios.

O Supremo Tribunal Federal, por sua vez, assentou entendimento de que, se houver previsão na Constituição Estadual e se esta estiver de acordo com os parâmetros constitucionais - desde as questões processuais até os limites materiais, passando pelos pressupostos formais -, os Estados podem adotar tal espécie normativa. Nota-se, pois, a necessidade de observância simétrica do processo legislativo federal. Tal precedente está cristalizado na ADIn $\mathrm{n}^{\circ} 425^{50}$ :

AÇÃO DIRETA DE INCONSTITUCIONALIDADE. PRELIMINAR. CONSTITUIÇÃO DO ESTADO. PROCESSO LEGISLATIVO. MEDIDA PROVISÓRIA. COMPETËNCIA DO GOVERNADOR PARA EDITÁLA. AUMENTO DE REMUNERAÇÃO DE SERVIDORES PÚBLICOS. INICIATIVA. DOAÇÃO DE BENS DO ESTADO. MAJORAÇÃO DO PERCENTUAL DE PARTICIPAÇÃO DOS MUNICÍPIOS NA ARRECADAÇÃO DO ICMS. EFICÁCIA LEGAL LIMITADA NO TEMPO. PREJUDICIALIDADE.

1. Podem os Estados-membros editar medidas provisórias em face do princípio da simetria, obedecidas as regras básicas do processo legislativo no âmbito da União $(\mathrm{CF}$, artigo 62).

2. Constitui forma de restrição não prevista no vigente sistema constitucional pátrio $\left(\mathrm{CF}, \S 1^{\circ}\right.$ do artigo 25$)$ qualquer limitação imposta às unidades federadas para a edição de medidas provisórias. Legitimidade e facultatividade de sua adoção pelos Estadosmembros, a exemplo da União Federal.

A Carta Constitucional, por sua vez, embora não a preveja expressamente, faz clara referência à figura das Medidas Provisórias estaduais:

Art. 25: Os Estados organizam-se e regem-se pelas Constituições e leis que adotarem, observados os princípios desta Constituição.

$[\ldots]$

\footnotetext{
${ }^{50}$ ADIn no 425/TO. Min Rel Maurício Corrêa. Julgamento: 03/09/2002.
} 
Revista da Faculdade de Direito da UERJ, V.2, n.22, jul./dez.2012

Pág in a | 16

$\S 2^{\circ}$ - Cabe aos Estados explorar diretamente, ou mediante concessão, os serviços locais de gás canalizado, na forma da lei, vedada a edição de medida provisória para a sua regulamentação.

Uma leitura a contrario sensu do artigo mencionado permite concluir que, ao vedar Medida Provisória estadual para a regulamentação de gás canalizado, reconheceu implicitamente a possibilidade de sua existência em relação a outros temas. Neste sentido, assinalou a Ministra Ellen Gracie que:

Concluir de forma diversa nos levaria a indagar inevitavelmente se teria sentido endereçar tal restrição ao presidente da República num dispositivo que trata apenas da atividade exclusiva dos outro partícipes da federação, que não a União, ou ainda por que motivo a Constituição Federal imporia uma proibição específica quanto à utilização pelos Estados-membros de um instrumento legislativo que lhes fosse vedado instituir. ${ }^{51}$

Embora o Pretório Excelso não tenha enfrentado a questão, uma interpretação sistemática e teleológica, à luz do princípio da simetria, permite a edição de Medidas Provisórias por Municípios desde que, mutatis mutantis, cumpram-se os mesmos requisitos exigidos aos Estados: deve haver previsão na Lei Orgânica Municipal em conformidade com os parâmetros constitucionais. Mesmo não havendo previsão constitucional semelhante a do artigo $25, \S 2^{\circ}$ atinente aos Municípios, a autonomia, mais especificamente a auto-organização, permitiria a edição de Medidas Provisórias municipais $^{52}$.

\section{Aspectos positivos e negativos do instituto da Medida Provisória}

Em uma primeira reflexão, poder-se-ia concluir que a Medida Provisória se trata de um instrumento jurídico potencialmente autoritário, tendo em vista a possibilidade de um vasto grau de atuação legislativa por parte do Chefe do Poder Executivo. É evidente que uma utilização excessiva e injustificada deste instituto acabaria por enfraquecer a representação popular, os partidos políticos e a própria separação de poderes, cláusula pétrea $^{53}$ e princípio constitucional fundamental no ordenamento jurídico vigente ${ }^{54}$. Isso porque a função legiferante do Executivo, em tese atípica, como já mencionado, de tão frequente transformar-se-ia em típica. Em última análise, acabar-se-ia com o

\footnotetext{
${ }^{51}$ Julgamento proferido em sede da ADIn 2.391/SC. Rel. Mim. Ellen Gracie, 16/08/2006.

52 Afirmam Nelson Nery Junior e Rosa Maria de Andrade Nery: "Não existe proibição no texto Constitucional para que os Chefes do Poder Executivo nos demais níveis (Estados e Municípios) editem medidas provisórias. Assim, tanto a Constituição Estadual quanto a Lei Orgânica do Município podem autorizá-los a editar MedProv, seguindo o modelo federal." (NERY JUNIOR, Nelson; NERY, Rosa Maria de Andrade. Constituição Federal Comentada. $2^{a}$ ed. São Paulo: Revista dos Tribunais, 2009).

${ }^{53} \mathrm{CF}$, art. 60, $\$ 4^{\circ}$ : Não será objeto de deliberação a proposta de emenda tendente a abolir: [...] III - a separação dos Poderes.

${ }^{54} \mathrm{CF}$, Art. $2^{\text {o: }}$ São Poderes da União, independentes e harmônicos entre si, o Legislativo, o Executivo e o Judiciário.
} 
Revista da Faculdade de Direito da UERJ, V.2, n.22, jul./dez.2012

Pág in a | 17

cerne do Estado Democrático de Direito ${ }^{55}$. Como bem conclui o eminente jurista Friederich Muller, o resultado é trágico, uma vez que:

sem precisar dissolver o Congresso Nacional, conforme a Constituição, o Presidente pode simultaneamente torná-lo impotente e desonerá-lo da responsabilidade - criando, assim, um círculo vicioso de desparlamentação e desdemocratização. ${ }^{56}$

No entanto, o escopo do instituto da Medida Provisória é conferir ao Executivo um instrumento para legislar nos casos em que não se pode aguardar o trâmite do processo legislativo comum. Em tese, pois, esse ato normativo é não apenas necessário como imprescindível para o funcionamento do Estado contemporâneo.

A consequência imediata da ausência de fiscalização foi o uso abusivo de medidas provisórias pelo Chefe do Executivo. Como a redação original do artigo $62^{57}$ não estabelecia as matérias passíveis de regulação por esse instrumento normativo e tampouco vedava sua reedição, o que era providência excepcional tomou a forma de método legislativo rotineiro.

Neste sentido, vejamos o que retrata o gráfico abaixo ${ }^{58}$ :

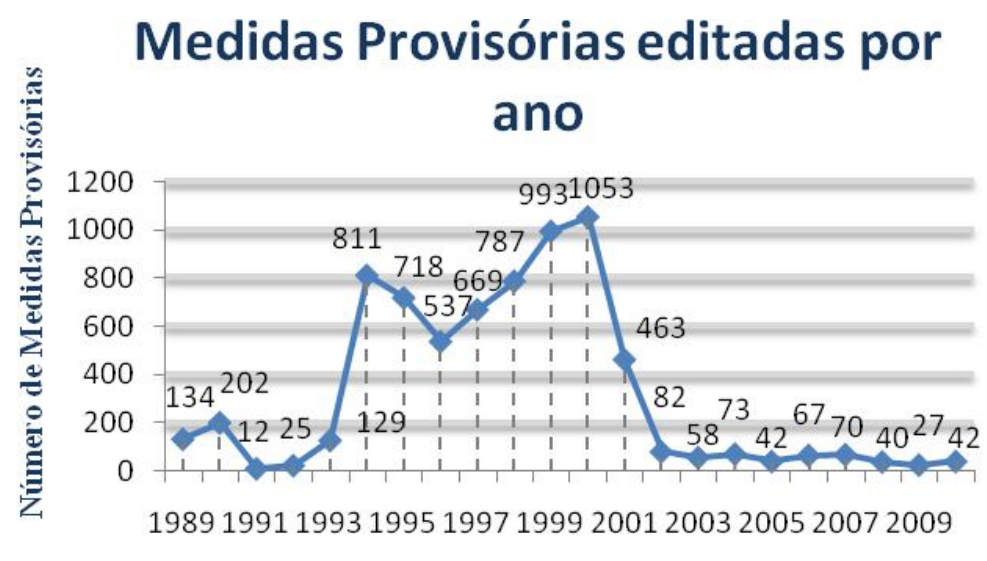

Ano

\footnotetext{
${ }^{55}$ No mesmo sentido, ver: ZIMMERMANN, Augusto. Curso de Direito Constitucional. $4^{\text {a }}$ ed. Rio de Janeiro: Lumen Juris, 2006.

${ }^{56}$ MULLER, Friederich. In: BONAVIDES, Paulo; MIRANDA, Jorge; AGRA, Walber de Moura (Coord.). Comentários à Constituição Federal de 1988. Rio de Janeiro: Forense, 2009.

${ }^{57}$ Redação original do art. 62: Em caso de relevância e urgência, o Presidente da República poderá adotar medidas provisórias, com força de lei, devendo submetê-las de imediato ao Congresso Nacional, que, estando em recesso, será convocado extraordinariamente para se reunir no prazo de cinco dias.

Parágrafo único: As medidas provisórias perderão eficácia, desde a edição, se não forem convertidas em lei no prazo de trinta dias, a partir de sua publicação, devendo o Congresso Nacional disciplinar as relações jurídicas delas decorrentes.

${ }^{58}$ Dados disponíveis em <http://www.planalto.gov.br/ccivil_03/mpv/quadro/_quadro\%20geral.htm>. Acesso em 25 out. 2011.
} 
Revista da Faculdade de Direito da UERJ, V.2, n.22, jul./dez.2012

Página | 18

Note-se que, como se sabe, as Medidas Provisórias foram instituídas com a promulgação da Constituição Federal, em 5 de outubro de 1988. Buscando uma análise isonômica, excluiu-se o ano de 1988 da estatística, uma vez que não há como comparar o número de medidas editadas em um ano com aquelas adotadas em apenas três meses. Pelo mesmo motivo, os dados vão apenas até 2010, haja vista a possibilidade de edições dos atos normativos ainda em $2011^{59}$.

A observação dos dados acima permite concluir que, no intervalo temporal em foco, foram editadas 7034 Medidas Provisórias pelos Presidentes da República. Não é difícil constatar, ainda mais com o alarmante número de 1053 medidas apenas em 2000 - configurando, nesse ano, uma assustadora média de 2,88 por dia - que o Executivo vinha agindo de forma abusiva. Certamente não surgiram mais de duas situações excepcionais por dia neste ano que justificassem tal aplicação.

Fator ainda mais alarmante reside na comparação feita entre o período ditatorial e o atual: entre abril de 1964 e março de 1985, os generais presidentes editaram 2272 decretos-leis. Ademais, valendo-se do instrumento das Medidas Provisórias, os presidentes legislaram duas vezes mais que o Congresso Nacional desde $1988^{60}$. Tal fato contribui para o descrédito de uma medida que deveria ser urgente e excepcional, mas se transforma em exercício ordinário do poder de legislar pelo Executivo, com grave comprometimento ao postulado constitucional da separação de poderes.

Neste sentido, aduz Celso de Mello:

Esse comportamento dos vários chefes do Poder Executivo da União, além de concentrar indevidamente na Presidência da República o foco e o eixo das decisões legislativas, tornou instável o ordenamento normativo do estado brasileiro que passou, em consequiência, a viver sob o signo do efêmero. ${ }^{61}$

Cabe destacar, porém, o significativo impacto positivo trazido pela Emenda Constitucional $\mathrm{n}^{\circ}$ 32, responsável, dentre outros aspectos, por impor limites à reedição e instituir limites materiais para a adoção de Medidas Provisórias, conferindo nova redação ao artigo 62 da Carta Magna. Como consequência imediata de tal emenda, é fácil verificar a enorme queda anual no total dos atos normativos em pauta, que a partir daí não ultrapassaram 82 por ano.

Ressalte-se que, o último ano do governo de Collor e os primeiros meses do de Itamar Franco, logo após a destituição do primeiro, representaram um período atípico, facilmente identificável como ponto destoante na série de dados.

\footnotetext{
${ }^{59}$ Isso porque este artigo foi escrito em outubro de 2011.

${ }^{60}$ Dados disponíveis em <http://www.egov.ufsc.br/portal/sites/default/files/anexos/14208-14209-1-PB.htm>. Acesso em 28 out. 2011.

${ }^{61}$ Declaração disponível em <http://www.stf.jus.br/portal/cms/verNoticiaDetalhe.asp? idConteudo=88830\& caixaBusca $=N>$. Acesso em 21 out. 2011.
} 
Revista da Faculdade de Direito da UERJ, V.2, n.22, jul./dez.2012

Página | 19

Apesar da redução, Medidas Provisórias continuam sendo editadas em contradição à delimitação constitucional. Foi o caso da MP 207/04 que, ao alterar a Lei nº 10.683/03, concedeu status de ministro ao então presidente do Banco Central, Henrique Meirelles. Ora, resta evidente que o caso em tela está em desacordo com os pressupostos constitucionais de urgência e relevância, possuindo caráter estritamente político. Até porque muitos $\operatorname{argumentam}^{62}$ que tal medida visava tãosomente frear as investigações promovidas pelos Procuradores da República contra Meirelles e deslocar a competência de apreciação das investigações para o Supremo Tribunal Federal ${ }^{63}$.

Interessante notar que tal fato não é característico de um ou outro governo, mas de todos. Tanto que, no momento da edição do chamado "Plano Collor" - por Medida Provisória - o então senador Fernando Henrique Cardoso chegou a afirmar que "constitui abuso da paciência e da inteligência do país a insistência de presidentes, que, numa recorrência autoritária empedernida, insistem em editar Medidas Provisórias"64. Contudo, o mesmo Fernando Henrique editou mais de 5000 medidas durante os seus oito anos de governo. ${ }^{65}$. Itamar Franco, por sua vez, dispôs do mesmo instrumento para nomear diretores de uma rádio de propriedade estatal.

É indubitável, porém, que, em um Estado Democrático de Direito, o Executivo necessita de um meio célere, ágil e eficaz para atender às demandas mutáveis da sociedade, que não podem prescindir do tempo necessário à realização do longo trâmite do processo legislativo federal. A patalogia, pois, reside na banalização do uso do instrumento da medida provisória. Seu uso cotidiano está em evidente contradição com a ratio legis do artigo 62 da Constituição, que prevê a edição desse ato normativo primário apenas em situações excepcionais, quais sejam, aquelas urgentes e relevantes.

\section{Considerações finais}

Algumas conclusões podem ser alinhavadas neste momento. Em primeiro lugar, os dados analisados anteriormente demonstram a evidente incompatibilidade entre a concepção ideal de Medida Provisória formulada pela doutrina e a sua roupagem factual, que muitas vezes configura uma verdadeira usurpação da função típica do Legislativo pelo Executivo. Neste sentido, a utilização

\footnotetext{
${ }^{62}$ Neste sentido, ver manifestação da Ordem dos Advogados do Brasil disponível em <http://direito2.com/oab/2004/nov/9/oab_repudia_mp_que_deu_status_de_ministro_a_presidente_do_bc $>$. Acesso em 23 out. 2011.

${ }^{63}$ Art. 102: Compete ao Supremo Tribunal Federal, precipuamente, a guarda da Constituição, cabendo-lhe: I - processar e julgar, originariamente: [...] c) nas infrações penais comuns e nos crimes de responsabilidade, os Ministros de Estado $[\ldots]$.

${ }^{64}$ Declaração disponível em <http://jusvi.com/artigos/947〉. Acesso em 22 out. 2011.

${ }^{65}$ SILVA, Paulo Napoleão Nogueira. Breves Comentários à Constituição Federal. Vol I. Rio de Janeiro: Forense, 2007.
} 
Revista da Faculdade de Direito da UERJ, V.2, n.22, jul./dez.2012

Página | 20

excessiva desse ato normativo acarreta, ainda, a drástica redução da importância político-institucional do Congresso Nacional, haja vista, inclusive, a previsão legal do trancamento de pauta nos casos de não apreciação da medida após quarenta e cinco dias.

Por outro lado, resta, ao nosso ver, a evidente a impossibilidade fática de se governar sem um o instrumento análogo ao da Medida Provisória, justificada por um periculum in mora legislativo. Isso porque verifica-se a existência de muitas questões urgentes e relevantes que não podem aguardar o tempo necessário ao trâmite regular do processo legislativo sem ensejar danos. Em um cenário de crise econômica, por exemplo, não seria razoável nem producente ter que aguardar todo o trâmite do projeto de lei para que uma medida crucial possa ser aprovada - correr-se-ia, pois, o enorme risco de danos advindos por conta da mora do processo legislativo. A Medida Provisória é, pois, imprescindível para o funcionamento do Estado contemporâneo.

Diante do exposto, é mister observar que o simples fato de o Poder Executivo utilizar-se de sua atribuição atípica de legislar não acarreta risco ao princípio da separação dos poderes. O referido postulado é ameaçado, no entanto, quando o Presidente da República, baseado no artigo 62 da Constituição Federal, dispõe, de forma abusiva e exorbitante, do instituto das Medidas Provisórias, não prestando observância aos pressupostos constitucionais de relevância e urgência. Agindo assim, o Poder Executivo não apenas assume função Legislativa alheia ao escopo constitucional, mas também compromete a segurança jurídica, a qual, por sua vez, está alicerçada nos parâmetros do Estado Democrático de Direito.

\section{Referências bibliográficas}

ATALIBA, Geraldo. Hipótese de incidência tributária. São Paulo: Malheiros, 2004;

BALERA, Felipe Penteado. Medida Provisória: o controle dos requisitos constitucionais de relevância e urgência pelo Congresso Nacional e pelo STF. Disponível em <http://www.esdc.com.br/RBDC/RBDC-14/RBDC-14-025-Artigo_Felipe_Penteado_Balera_ (Medida_Provisoria).pdf>. Acesso em 20 out. 2011.

BEZERRA, Paulo Cesar Santos. Mutação Constitucional: os processos mutacionais como mecanismos de acesso à justiça. Disponível em <http://www.sefaz.pe.gov.br/flexpub /versaol/filesdirectory/sessions579.pdf>. Acesso em 27 out. 2011.

BONAVIDES, Paulo; MIRANDA, Jorge; AGRA, Walber de Moura (Coord.). Comentários à Constituição Federal de 1988. Rio de Janeiro: Forense, 2009.

CARVAlHO FILHO, José dos Santos. Manual de Direito Administrativo. 25 a ed. Rio de Janeiro: Lumen Juris, 2010.

CLÈVE, Clèmerson Merlin. Medidas Provisórias. 2ª ed. São Paulo: Max Limonad, 1999.

DERZI; MACHADO, Misabel de Abreu. Direito tributário, direito penal e tipo. São Paulo: RT, 1988; 
Revista da Faculdade de Direito da UERJ, V.2, n.22, jul./dez.2012

Página | 21

FERNANDES, Bernardo Gonçalves. Curso de Direito Constitucional. Rio de Janeiro: Lumen Juris, 2010.

LENZA, Pedro. Direito Constitucional Esquematizado. 15ª ed. São Paulo: Saraiva, 2011.

MAIA, Paula Oliveira; LIMA, Eduardo Martins. As Medidas Provisórias e o Poder Judiciário: o controle jurisdicional dos pressupostos de relevância e urgência. Disponível em <http://www.conpedi.org.br/manaus/arquivos/anais/Paula\%20Oliveira\%20Maia\%20e\%20Eduardo \%20Martins\%20de\%20Lima.pdf>. Acesso em: 22 out. 2011.

MELlO, Celso Antônio Bandeira de. Curso de Direito Administrativo. 20a ed. São Paulo: Malheiros, 2006.

MENDES, Danielle Patrícia Guimarães. A medida provisória sobre matéria tributária em face da Emenda Constitucional $n^{o}$ 32. Jus Navigandi, Teresina, ano 7, n. 58, 1 ago. 2002. Disponível em: $\langle$ http://jus.com.br/revista/texto/3084>. Acesso em: 3 dez. 2011.MORAES, Alexandre de. Direito Constitucional. $20^{a}$ ed. São Paulo: Atlas, 2006.

MORAES, Guilherme Peña de. Curso de Direito Constitucional. $2^{\mathrm{a}}$ ed. Rio de Janeiro: Impetus, 2008.

NERY JUNIOR, Nelson; NERY, Rosa Maria de Andrade. Constituição Federal Comentada. $2^{\mathrm{a}}$ ed. São Paulo: Revista dos Tribunais, 2009.

PAULO, Vicente; ALEXANDRINO, Marcelo. Direito Constitucional Descomplicado. $7^{\mathrm{a}}$ ed. São Paulo: Método, 2011. Pág. 546.

SILVA, José Afonso da. Curso de Direito Constitucional Positivo. $27^{\mathrm{a}}$ ed. São Paulo: Malheiros, 2006.

SILVA, Paulo Napoleão Nogueira. Breves Comentários à Constituição Federal. Vol I. Rio de Janeiro: Forense, 2007.

ZIMMERMANN, Augusto. Curso de Direito Constitucional. $4^{\mathrm{a}}$ ed. Rio de Janeiro: Lumen Juris, 2006. 